\title{
PREFACE TO THE U.S. EDITION ${ }^{1}$
}

After forty years of scholarship that has carefully pawed over the data on which the research effort reported in this book was based, and after the gradual publication, in somewhat parallel sequence, of a major portion of Heidegger's Collected Works (the Gesamptausgabe) that contained prodigious amounts of material relevant to this research but inaccessible to the writer when it was undertaken, any serious effort to "revise" the original text in preparation for its U.S. publication in a more studentfriendly form than the original is, as a practical endeavor, simply not feasible. One would have to start all over again. What does seem feasible, however, as a way of introducing the text to a new generation of readers, is to briefly discuss a single theme, characteristic of (and central to) the book's entire argument, that may suggest the sense and continuing relevance of the work as a whole.

It will be clear to anyone familiar with Heidegger scholarship over these years that the apparent difference between the philosophical style of an early Heidegger (for example, the author of Being and Time), which in the following study I labeled "Heidegger I," and that of a much later period, which I designated roughly as "Heidegger II," became a bone of contention among Heidegger's interpreters and provoked more sound and fury

1 The substance of this essay first appeared as "From Phenomenology Through Thought to a Festschrift. A Response," Heidegger Studies 13 (1997): 1 7-28. 
than it perhaps deserved. ${ }^{2}$ The debate itself has long since, like any storm, spun itself out, yet it remains part of the Heidegger story in the United States and deserves at least a historical note. It seems worthwhile for the contemporary reader to understand how this distinction came about in order to assess what value it may or may not retain today, long after it was first proposed. Under the circumstances, I hope the reader will be indulgent with the inevitably autobiographical tone of the following account.

When I first arrived in Freiburg in the early fall of 1955 , in order to follow Heidegger's announced lecture course on The Principle of Reason, ${ }^{3}$ I had the extraordinary good fortune to share lodgings with an Italian student, Virgilio Fagone, who was finishing his dissertation on Heidegger for the Gregorian University (Rome) under the direction of a German professor with a special interest in Heidegger, J.-B. Lotz (a contemporary and friend of the eminent theologian Karl Rahner, both of them former students of Heidegger in the turbulent thirties). Fagone was a small, ebullient man who loved life, loved philosophy (especially à la Heidegger), and loved to talk. As a personality, he was bubbling champagne. He was also an exceptionally gifted man, whose lucid mind and solid erudition had earned him (through the mediation of Professor Max Müller-former student become personal friend of Heidegger) an invitation to participate in Heidegger's by-invitation-only seminar on Hegel's Logic that ran concomitantly with the public lecture course and is known to the reading public by the presentation with which Heidegger himself concluded it, "The Onto-theo-logical Constitution of Metaphysics." 4

For my own part, I was the total innocent. I was beginning graduate studies in order, eventually, to teach metaphysics, and I knew that Heidegger was a contemporary who had something to say about it. I had been accepted at the Higher Institute of Philosophy (Louvain) and had made some preliminary contact

2 William J. Richardson, Heidegger: Through Phenomenology to Thought, preface by Martin Heidegger. $3^{\text {rt }}$ ed. (The Hague: Martinus Nijhoff, 1974).

3 Martin Heidegger, The Principle of Reason, trans. R. Lilly (Bloomington: Indiana University Press, 1991).

+ Martin Heidegger, "The Onto-theo-logical Constitution of Metaphysics" in Identity and Difference, trans. J. Stambaugh, $2^{\text {ndt }}$ ed. (New York: Harper \& Row, 1974). 
with the Heidegger specialist there, Alphonse De Waelhens, ${ }^{5}$ who had tentatively agreed to supervise my work. Beyond that, I knew practically nothing. Fagone mistook my interest for knowledge and would return from his seminar sessions with Heidegger burning with eagerness to pour out all he had heard on my attentive but uncomprehending ears. In particular, he kept stressing (for reasons I did not yet understand) the coherence between what Heidegger was then doing with Hegel's Logic and what he had attempted in Being and Time. ${ }^{6}$ The secret? Whispered with raised eyebrows and a roll of the eyes, some mysterious alchemy called "the Kehre." All those who thought that with Being and Time Heidegger had reached some kind of dead end were simply oblivious to the wonderfully transformative power of the Kehre.

Slowly, I realized that De Waelhens, dean of the French commentators on Being and Time and Doktorvater-designate of my thesis-to-be, was precisely one of these unenlightened. Recalling my initial conversations with him, I remembered his saying how he felt that the original project of Being and Time, so full of promise, had simply gone bankrupt, and that Heidegger, in frustration and disappointment, had turned to some kind of poetizing-sorry substitute for one so gifted for rigorous philosophical analysis as he. Clearly, there were at least two ways of understanding the meaning of the later Heidegger or, at least, two ways of conceiving the relationship between the early and the later periods: as escape or as fulfillment. In this sense, the question of "two" Heideggers was, from the beginning (in 1955), a given-the use of "I" and "II" was simply the most practical shorthand device I could think of to refer to them in note-taking. The task would be to find some way of examining the relationship between them.

But how? Here, too, Fagone had a suggestion, though it tumbled out one evening inadvertently, à propos of something completely other: "Foundational thinking (Das wesentliche Denken)! Now there's an interesting idea! How does it relate to the phe-

\footnotetext{
5 Alphonse De Waelhens, La Philosophie de Martin Heidegger (Louvain, Belgium: n.p., 1941).

6 Martin Heidegger, Being and Time, trans. J. Stambough (Albany: State University of New York Press, 1996).
} 
nomenology of Being and Time?" The idea stuck. I spent the semester casting about for a suitable dissertation topic and considered many, but in the end this seemed the most promising of all. Before the term was over, I revved up enough courage (naïve brashness?) to approach the Lion himself in his den during one of the scheduled "office hours" that followed each public lecture. Would the tracing of the notion of the "thinking of Being" be a suitable dissertation topic? A firm " $J a$ " was all the answer I needed, and the decision was made.

De Waelhens was appalled. "Are you serious? Do you really want to work on that?" he asked. Dismayed by his reaction but bolstered by Heidegger's approval, I had the sinking feeling that this might be bite-the-bullet time and, with deep breath and anxious gulp, muttered, "Yes." He sighed deeply, shrugged his shoulders, and shook his head in disbelief as if to say, "You must be out of your mind"- - but did not refuse to provide supervision. It turned out to be an ideal match. De Waelhens deeply disliked the later Heidegger (had Heidegger's Nazi experience influenced his attitude?), but he took his professional obligation seriously: he read what I wrote carefully and incisively; his criticism was forthright, often expressed with wry, half-smile humor ("un peu de distance, quand même"); and he remained committed to the task long after the direction of the work pointed toward a conclusion that clearly would challenge his own deeply held views. Best of all, he helped me understand the burden of freedom and showed by very concrete example what it meant to "let [someone] be."

Course work in Louvain finished, research resumed in earnest back in Freiburg. When I had worked through the texts of the early period up to (and including) "On the Essence of Truth" (1930-43), in which the phrase "the thinking of Being" first appeared in the published work and the shift of focus from Dasein to Being that characterized (as far as I could see) the later period was first clearly discernible, ${ }^{7}$ I was tired of being a schoolboy and wanted to wrap up the doctorate so as to be able to return home to go to work. Subsequent research, I thought,

7 Martin Heidegger, "On the Essence of Truth," trans. J. Sallis, in Basic Writings, ed. D. F. Krell, $2^{\text {mt }}$ ed. (San Francisco: HarperSanFrancisco, 1993), I I I-38, 135. 
could be left to the postdoctoral years. De Waelhens advised against that plan. "Your work is solid enough, but you have dealt with texts that others, too, have interpreted. Now that you have both a method and a momentum in using it, you are in a position to interpret texts that others have not yet worked through. If you finish what you have started and work through the rest of his recently published texts, this could become a real contribution that would be of help to everybody." And so, with some reluctance, I continued. I was aware, of course, that there were a number of unpublished manuscripts around that could be very illuminating, and I began to collect them, or at least to photograph them. But in that pre-Xerox era this was a cumbersome and time-consuming task that yielded unreliable (ultimately, unusable) results. So I decided to make a virtue of necessity and limit my research to the published texts for which Heidegger himself could be held responsible. ${ }^{8}$

Working conditions in Freiburg were congenial. What began as a small reading group grew into a circle of friends, one of whom, Michael Theunissen, would later become an eminent member of Germany's academic philosophical scene. On the professorial level, Eugen Fink, Bernard Welte, and Max Müller were all accessible; but it was Müller, to whom I was first introduced by Fagone, who quickly became teacher, mentor, and friend. Insight came slowly. Texts such as Introduction to Metaphysics (1935) ${ }^{9}$ and some of the interpretations of Hölderlin (for example, "Andenken," 1943) ${ }^{10}$ clearly belonged to the later period yet just as clearly contained configurations that conformed to patterns of Being and Time. With the "Letter on Humanism" (1947) ${ }^{11}$ the issue of the Kehre was explicitly introduced, and the shift from the thought patterns of the early

8 Even this presented problems. Recall, for example, the unannounced and unexplained shift in the text of the first edition (1943) of the "Epilogue" to What Is Metaphysics? which read, "being indeed comes-to-presence without beings" (my emphasis), to the second edition of the same text (1949), which read, "Being never comes-to-presence without beings" (my emphasis). This demanded some hermeneutic acrobatics, after all (cf. Richardson, Heidegger, 562-65).

9 Martin Heidegger, Introduction to Metaphysics, trans. R. Mannheim (New Haven: Yale University Press, 1959).

10 Martin Heidegger, Erläuterungen zu Hölderlins Dichtungen (Frankfurt: Klostermann, 1944), 75-1 43 .

11 Martin Heidegger, "Letter on Humanism," trans. F. A. Capuzzi and J. G. Gray, in Basic Writings, ed. Krell, 23I. 
Heidegger to those of the later period were given a local habitation and a name. It was here that he confirmed the interpretation that I had proposed for the essay "On the Essence of Truth." It was particularly reassuring to find the following text:

The lecture "On the Essence of Truth" ... provides a certain insight into the thinking of the turn from "Being and Time" to "Time and Being." This turn is not a change of standpoint from Being and Time, but in it the thinking that was sought first arrives at the location of that dimension out of which Being and Time is experienced, that is to say, experienced from the fundamental experience of the oblivion of Being. ${ }^{12}$

After meditating on this text, I fell upon the idea (actually, to be more precise, it fell upon me as I tumbled out of bed one morning when I was back in Louvain to consult with De Waelhens) that the later period could be thought of as an attempt to retrieve (Wiederholung) the unsaid of the earlier period-what was not and could not be said in the mindset of Being and Time. That would settle the question about "two" Heideggers: the hypothesis of the later "retrieving" the earlier would account for unity/continuity of the two in a single enterprise yet also explain the difference of focus and style between them that gave De Waelhens and company such dyspepsia. Hooray!

But this did not do much for the question of thinking and its possible relationship to the phenomenology of Being and Time. The most direct address to the question occurs in the vociv gival correlation as analyzed in the Introduction to Metaphysics ( 1935$),{ }^{13}$ in which thinking is conceived essentially as an active acceptance of Being. The notion comes full circle in What Is Called Thinking? (1952), in which the same fundamental structure is discernible in another text of Parmenides as correlation

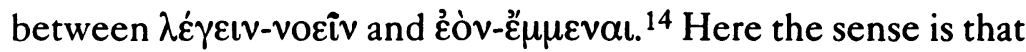
thinking means to let-lie-forth ( $\lambda \dot{\varepsilon} \gamma \varepsilon ı v)$ and accept-the-care-of

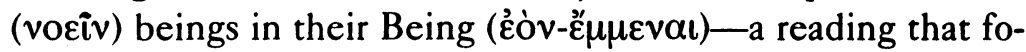
cuses more sharply than the former text on the ontological dif-

12 Ibid., 243.

13 Martin Heidegger, Introduction to Metaphysics, $115-96$.

14 Martin Heidegger, What Is Called Thinking? trans. F. Wieck and J. G. Gray (New York: Harper and Row, 1954), 163-244. 
ference as such between Being and beings. In another context of the same work, thinking (Denken) is considered on one hand as (dynamic) structure, that is, "re-cord" (Gedächtnis), and on the other hand as process, that is, "thanking" (Danken). In short, the nature of thinking is for Dasein, whose own Being consists in its openness to Being, to acquiesce in an accepting gesture of gratitude to Being as it reveals itself through Dasein in finite fashion. But this corresponds exactly to what in Being and Time was the gesture of resoluteness (Entschlossenheit), that supreme moment in the phenomenology of Dasein when it lets itself be (manifest as) what it is in all its finitude. This much seemed clear to me after studying What Is Called Thinking? (1952), but I kept looking in the subsequent works for some kind of smoking gun evidence for this transformation that no one could deny. I was about to give up when, finally, Conversation on a Country Path about Thinking (1944-46) appeared in 1959, offering the following text: "Thus, the essence of thought, i.e., release unto [Being], would be resoluteness unto truth in its presencing" (Dann wäre das Wesen des Denkens, nämlich die Gelassenheit zur Gegnet, die Entschlossenheit zur wesenden Wahrheit). ${ }^{15}$ Eureka! There was the smoking gun. The time had come for the real test: to present these findings to Heidegger himself and face up to his critical assessment of them.

In requesting an interview, I included a letter of recommendation from Max Müller, which I am certain had much to do with the response, and a twenty-five-page summary of my argument. When Heidegger pulled the summary out of a folder, I was shocked to see that every page (apparently) had been stroked, counterstroked, circled, and daggered to death with red ink. Obviously, he had read my text carefully, but the only two negative comments he offered were both minor, only one of which I recall now: I had misused the word "subjectivity" with regard to Leibniz. The proper term in the case of Leibniz is not Subjektivität but Subjektität. Amen! Otherwise, Heideg-

15 Martin Heidegger, "Conversation on a Country Path about Thinking," Discourse on Thinking, trans. J. Anderson and E. H. Freund (New York: Harper Torchbooks, 1966), $58-90,81$. 
ger seemed to accept the whole package. We spent the rest of the time (which included coffee and cookies served by Frau Heidegger) talking about many other things than my text as such.

The following day, on the way to the University, I bumped into Müller's assistant, who asked me how the visit had gone. I told him that from my point of view I thought it had gone pretty well but that I had not yet had time to absorb it. He then told me that, following the interview, Heidegger had talked to Müller by phone to say, in effect (as I was given to understand it): "Who is this guy? So many have gotten me wrong, but here is someone who has gotten me right-and he's an AMERICAN! How is that possible?" Müller was justly pleased and could take credit for his tutelage, mediated so well in the beginning by Fagone. I was astonished and soon began to have wild thoughts-like . . . even . . maybe . . . well, why not go for broke? ... a preface! With Müller's encouragement I asked and received "in principle" a promise of a preface, provided that I submit one or two questions that could be addressed directly. These were carefully honed (after much reflection and consultation with my Heidegger-savvy friends) three years later when the book was already in print and scheduled for publication. The substance of my letter of March I, 1962, was simple indeed: "You will recall that you were kind enough to offer to write a preface for my book, From Phenomenology to Thought, provided I formulate one or two questions that might be directly addressed. The questions that seem most relevant to me are these. ... In advance, please be sure of my deep gratitude, etc." There was no more immediate context for them than that.

When Heidegger's preface arrived a month later, I was ecstatic. In the first place, the change he suggested in the title (from From to Through [Phenomenology to Thought]) was fruitful, easily made, and engaged his authority in the formulation of it. Great! More particularly, I was delighted (perhaps too hastily) with what he said about my use of the formulae "Heidegger I" and Heidegger II": "The distinction you make between Heidegger I and II is justified only on the condition that it is kept constantly in mind: only by way of what [Hei- 
degger] I has thought does one gain access to what is to-bethought by [Heidegger] II. But the thought of [Heidegger] I becomes possible only if it is contained in [Heidegger] II." 16 I could not conceive of a clearer confirmation than this of the inferences I had drawn after a long journey through his texts and articulated in my conclusion to the book-a text, in fact, that he had never read. This had been composed after our interview in February, 1959 (three years earlier), and had long since been locked up in print.

Relying on texts that suggested the receptive character of his thought as early as I92 I, I had argued:

From this it becomes clear that, no matter what must be said about the orientation of Heidegger I in SZ (1927), the experience which comes to expression in Heidegger II (where Being as simultaneous revealment-concealment holds the primacy over thought) dates at least from 1921 , when he was already engaged in what he later calls the historical process of thought-ful dialogue. What else is there to conclude than that Heidegger II is more original than Heidegger I, went before him along the way? By the same token we are given to understand that if Heidegger [takes a turn in his way] in order to become Heidegger II, the reason is not that the effort went bankrupt but that the thinker simply left one place in order to gain another along the same way. "What abides in thought is the way."17

It would be from that other place that Heidegger II could be said to "retrieve" the unsaid of Heidegger I. Beyond them both and motivating them both I postulated a more primordial experience still that I called (rightly or wrongly) the "Ur-Heideggèr."18

By this I had in mind the original experience of the Beingquestion as occasioned by his reading of Brentano's thesis on Aristotle, the event when it all began. For the discovery of the Being-question was also the discovery of its forgottenness. Heidegger says as much when he first spoke publicly of the Kehre in the "Letter on Humanism": "This turning is not a change of standpoint of Being and Time, but in it the thinking that was sought first arrives at the location of that dimension out of which Being and Time is experienced from the fundamental experience of the oblivion of Being." 19 Clearly, it was the Being-

16 Martin Heidegger, preface to Richardson, in Richardson, Heidegger, p. xxii.

17 Ibid., 632.

18 Ibid., 633 .

19 Martin Heidegger, "Letter on Humanism," in Basic Writings, ed. Krell, 232-33. 
question in its forgottenness that energized his reach for the unreachable star to the very end.

In our conversation, he expressed himself on the matter with a nuance slightly different from what, as far as I know, he says elsewhere. My recollection is that he put it this way: "After discovering the Being question as a question in Aristotle, I read Aristotle (and others) assiduously to find an answer to it, but found none. Simultaneously with the Being-question, then, was the experience of its forgottenness. Nonetheless, Aristotle and all the others used the word 'is,' hence had some understanding of what it means even though they had failed to pose the question of what 'Is' (Sein) as such means. If one were to pursue this question, one would have to begin by investigating that lived (but unnoticed) understanding of 'is' that is in Aristotle and, for that matter, in all of us (Dasein). The best instrument available for such a task obviously was phenomenology. So. . .." It was with the expectation that he would repeat this sequence in writing that I formulated the first question for him to address in the preface. In fact, he chose not to do so. I was very aware of all this, however, in formulating my conclusion and made the best case I could for an "Ur-Heidegger" with the data available for citation. In any case, Heidegger's remarks about "Heidegger I/II" I took to be a clear and totally unanticipated confirmation of my own conception of the relation between them as stated in the conclusion, and I was very happy about it. I thought about adding a note to the translation of the preface, pointing out its correlation with my conclusion, but rejected the idea as too obvious, hence an indiscreet overkill that would annoy more than it would enlighten the attentive reader. What a mistake!

Let this say, then, that from beginning to end, from De Waelhens (who read with a hermeneutic of suspicion every fragment, piece by piece), through all sorts of lesser (but highly exigent) folk, through major critics (for example, Max Müller, Henri Birault, and Emmanuel Levinas), to Heidegger himself, no one-but no one!- ever raised the slightest objection to my use of the I/II formula-instinctive, highly convenient shorthand that gradually insinuated itself into the formal text. The difference between Heidegger I and II (in style, tone, and 
focus) was (to me, working with the texts available 1955-60) a given; the unity and continuity between them, I believed, had been carefully demonstrated. It was not until the book was published and I returned home to try to find some way into the philosophical community that the Grand Illusion was shattered and the pernicious Scandal of this distinction was finally laid bare for all the world to see.

But I noticed that the reviews usually cited nothing more than my introduction; and without plowing through them all over again, I have no memory of anyone who ever addressed the I/II issue as finally crystallized in the conclusion at all-still less in direct confrontation with Heidegger's comments in the preface. Yet for me, the conclusion, not the introduction, was the culmination of the study. Even so astute a reader as Reiner Schürmann, for example, in rejecting this terminology, cites Heidegger's comments as "reservations." 20 As indicated above, I found them to be in no way "reservations" about the terminology but the clearest possible confirmation of its validity. What element of "reserve" was in them I felt I had anticipated and taken account of in the conclusion. Significantly, Schürmann gives his reference to page 22 of my book (introduction), not to pages 632-33 (conclusion). The "most unkindest cut of all," however, came one evening at a Society for Phenomenology and Existential Philosophy smoker when one well-known, well-published, pipe-smoking Heideggerian came up to me, feeling totally isolated, and said in kind, avuncular fashion: "All these people are bad-mouthing you for your two-Heidegger thing. I want you to know that I, at least, am on your side. I, too, believe that there really are two Heideggers." Puff, puff, puff!

None of this should be taken to suggest that I would claim that there is no other way to understand Heidegger's development than the one I proposed. Schürmann's conception of things, for example, must be respected as a compelling one; and the more we know about Heidegger's previously unpublished work, the more closely we can follow every twist and

20 Reiner Schürmann, Heidegger. On Being and Acting: From Principles to Anarchy, trans. C.-M. Gross (Bloomington: Indiana University Press, 1990), 17 and n. 43. 
turn in his zig-zag way through the prodigious twenties, the more nuance we must supply to the notion of Kehre as such. As for my own proposal-the essentials of which are that there was a Kehre (by Heidegger's own testimony) and that there was, therefore, a pre-Kehre (what I took to be Heidegger I-typified by Being and Time) and a post-Kehre (what I took to be Heidegger II-typified, say, by Time and Being)-I would still defend its cogency as a plausible hypothesis for appreciating the whole of the Heidegger phenomenon taken in the sum.

When I speak of the need to nuance the understanding of Kehre in the light of the current availability of Heidegger's previously unpublished work, I have in mind such a text as his Contributions to Philosophy (From Enowning) (1936-1938),21 which, published in 1989 , was obviously inaccessible when my own work was done. There we got a closer look at the several moments of the turn from I to II, in which the "analytic of Dasein" is retained even as the perspective of "fundamental ontology" is abandoned, precisely through the kehrige Bezug des Seyns, that is, "the turning-relation-in Being itself" as this becomes apparent through the thinking of Ereignis. Contributions to Philosophy, for example, helps us to understand why and how such essential ingredients as "projection" and "thrownness" in the existential analysis of Dasein (Heidegger I) remain equally essential to the thinking of ereignis (Heidegger II), precisely in its need for these very same characteristics of Dasein in order that it may come to pass at all. Given such clarifications as this that have become common coin among Heideggerians over forty years of scholarship, is there still need for so pedestrian a distinction as that between Heidegger I and II? Whatever its history, does it serve any longer a useful purpose?

There is no doubt that Beiträge zur Philosophie (Vom Ereignis), as interpreted by him, adds welcome precision to what I propose in my conclusion, but in no way, as far as I can see, does it gainsay what is said there. Given the history of my

21 Martin Heidegger, Contributions to Philosophy (From Enowning), trans. P. Emad and K. Maly (Bloomington: Indiana University Press, 1999). 
own involvement with the problem, a judicious answer to this question must be left to others, but, with reserve for better judgment, I would argue that the distinction is, indeed, still a useful one, at the very least for heuristic purposes. Contributions to Philosophy, for all its power (it is touted as Heidegger's "second major work" after Being and Time), is hardly the most lucid of his writings; and some find in it, remarkable though it is, good reason to understand why he chose not to publish it. At best, it is an extremely difficult text that makes heavy demands upon the most sophisticated Heideggerians, hardly bread for the proletariat for whom the I/II distinction was invented. It is hard to imagine what the plodding scholar would have made of Contributions to Philosophy in 1938, that is, without the subsequent works up to and including Time and Being $(1962)^{22}$ to illuminate it. It is not even clear what Heidegger made of it himself. Certainly, there would have been no preface to offer us the perspective of our hindsight. Just as Heidegger's own journey of self-discovery was long and arduous, so it is hardly inappropriate that the journey of those who try to follow him over difficult terrain be marked by dark ravines and valleys that may wisely be left for subsequent exploration in order that the primary journey may be finished at all. If it is not too pretentious, I would like to make my own in this regard the spirit of Heidegger's brief prologue to the ninth edition of Sein und Zeit, in which he remarks: "The way [this study follows] still remains even today a necessary one if the question about Being is to stir our Dasein." 23 Stressing the point in our interview (1959), he insisted: "I would write Being and Time all over again now, if it were still necessary to do so." It is in this sense, then, that I do think the I/II distinction remains useful-no more than that, perhaps, but heuristically useful-at least for the proletariat, heavily burdened as we are by the poverty (Armut) of thought that, when all is said and done, makes beggars of us all.

And De Waelhens? He encouraged the enterprise, praised

22 Martin Heidegger, "Time and Being," in On Time and Being, trans. J. Stambaugh (New York: Harper and Row, 1972).

${ }^{23}$ Martin Heidegger, Sein und Zeit, neunte Auflage (Tübingen, Germany: Niemeyer, 1960). p.v. 
what he could find good in it, and supported it to the very end. But he was never for a moment convinced-he went to his grave happy in his disbelief. ${ }^{24} \mathrm{He}$ was a fine man, a true philosopher, and a great mentor. May he rest in peace!

\author{
William J. Richardson, Ph.D. \\ September 2002
}

24 What his real feelings were would appear only long after the book had appeared and he was given his day in court. Invited by the editor of International Philosophical Quarterly to write a review essay of my work, under the rubric of "Contemporary Currents" (Alphonse De Waelhens, "Reflections on Heidegger's Development. A propos a Recent Book," Intermational Philosophical Quarterly 5 [1965]:497-502), he treated the book with great respect but then made his own position clear. The tenor of his position may be divined from his concluding paragraph: "With Heidegger, thought, in the sense of What Is Called Thinking?, comes down to projecting a fundamental experience without place, without home, without partners unable to be situated, unable (when all is said and done) even to be uttered, and with regard to which all the discernible modalities of human existence are only deviated productions. There is no true thought outside of that experience, no true experience of Being outside of that one. And of this experience itself, one cannot say since all language is borrowed from it-whether it is Being, the revelation of Being in man, or the contribution of man to Being. All these expressions pose all over again the very questions that they elucidate. This 'dubious struggle' in which everything is at stake cannot fail to remind us of a certain phrase of Hegel aimed at the nocturnal character of Schelling's Absolute, and which we will not have the irreverence to cite, for after all we must leave to the genius of a Hegel the cruelty of Hegelian irony." The reference, obviously, is to Hegel's characterization of Schelling's Absolute as the "night in which all cows are black." Cf. G. W. F. Hegel, Phänomenologie des Geistes (Hamburg: Meiner, 1952), 19, cited ibid., 502n.2 I. 